\title{
Strategies for Controlling Cocoa Pod Borer, Conopomorpha cramerella Snellen, on Cocoa Farmers in Langkat District, North Sumatra, Indonesia
}

\author{
Ahmad Saleh ${ }^{{ }^{*},}$, Armaniar ${ }^{2}$, Abu Hassan Ahmad ${ }^{3}$ \\ ${ }^{1}$ College of Agricultural Science Agrobisnis Plantation, Medan 20226, Indonesia \\ ${ }^{2}$ Pembangunan Panca Budi University, Medan 20122, Indonesia \\ ${ }^{3}$ School Biological Sciences, University of Science, Penang 11800, Malaysia \\ *Corresponding author. Email: hasholeh@gmail.com
}

\begin{abstract}
Cocoa Pod Borer (CPB) Conopomorpha cramerella Snellen is the primary cause of significant yield loss up to $80-90 \%$ for smallholders. It is hard to control the pest because most of their lives are in cacao pods, which makes them protected from natural enemies and insecticide applications. This study was conducted to obtain $\mathrm{CPB}$ control strategies that can be applied by farmers and to increase their cocoa productions. We observed CPB infestation, the population of its natural enemies Cocoa Black Ant (CBA) Dolichoderus thoracicus along Cocoa Mealybugs (CM) Exallomochlus hispidus, and the cocoa canopy at 10 cocoa farms from March 2018 to June 2019. Mutual association was found between the cocoa black ants and cocoa mealybugs in $62 \%$ of the cocoa trees that grown under shade trees. They were found nesting on coconut (Cocos nucifera), soursop (Annona muricata), kapok (Ceiba pentandra), and jackfruit (Artocarpus heterphyllus), that grow around or mixed with cocoa trees inside the farm areas. Most of the cocoa trees had dieback because they did not apply fertilizer and, in some areas, there were no shade trees. In Langkat District, the cocoa black ants and cocoa mealybug symbiosis and populations have grown naturally. Thus, it is enough to provide empty artificial nests of ants as a strategy to increase their populations in the cocoa farms.
\end{abstract}

Keywords: Conopomorpha cramerella, Dolichoderus thoracicus, Exallomochlus hispidus, cocoa, pest

\section{INTRODUCTION}

The cocoa pod borer (CPB) Conopomorpha cramerella Snellen (Lepidoptera: Gracillariidae) is one of the key pests of cocoa that arduous to control due to the natural behaviour that protect them from enemies or control techniques [1-3]. The larvae of CPB live inside the cocoa pod and active to feed on mucilage and placental [4]. CPB attacks on younger pods resulting in malformation and clumped beans, making them unextractable during harvesting $[2,5,6]$. The yield loss caused by CPB can reach up to $80 \%$ [1].

Cocoa is the source of living for more than 2,186 farmers in Langkat District, North Sumatra, with an average area of 1,616 ha, but the yield per ha is ca. $558 \mathrm{~kg} / \mathrm{ha} /$ year [7], and some farmers can only produce less than 400 $\mathrm{kg} / \mathrm{ha} /$ year [8]. Most of the farmers failed to control CPB with insecticides resulting in low quality of cocoa beans, which led to decreasing income per capita. Thus, the farmers could not maintain the trees properly using cultural practices such as pruning and fertilizer application. Therefore, total production in these areas reduces more than $90 \%$ [8].

Cocoa Black Ants (CBA), Dolichoderus thoracicus Smith (Hymenoptera: Formicidae) is known as a biological agent in controlling $\mathrm{CPB}$ in Indonesian cocoa plantations [9-
11]. To control CPB attacks, farmers in North Sumatra applied the Integrated Pest Management strategies with an emphasis on biological control, i.e., the establishment of CBA, cocoa mealybug (CM) Exallomochlus hispidus, and followed by 7-day harvesting round and buried of cocoa husks [12]. CBA is mutually associated with $\mathrm{CM}$. The high population of CBA and $\mathrm{CM}$ required in controlling $\mathrm{CPB}$, and the success rate would be higher if there are at least $70 \%$ harvested pods occupied by CBA and CM [13]. CBA also a biological agent for controlling Helopeltis theobromae, Miller (Hemiptera: Miridae) in large scale cocoa plantations in North Sumatra and East Java [14-16].

The CBA occurred naturally in cocoa plantations, where $62 \%$ of cocoa trees in shaded areas have been occupied by CBA [8]. CBA build their arboreal nests for their breeding sites. In natural condition, where cocoa is grown under coconut palm, CBA nests can be found under folded coconut palm or cocoa leaves, cocoa leaf litter, within the laterally curled leaflets of dried coconut fronds, underneath the dried sheath that once served to protect the coconut inflorescence and under the proximal ends of live coconut leaflets $[9,17,18]$. The population growth of CBA depends on their nests and food sources, as well as the absence of antagonist ants. Usually, population density is controlled by food resources and breeding sites as well as by predation [19]. Saleh [12] reported that based on CBA preferences to 
build nests in cocoa leaf litter and coconut leaflet tubes, he used the materials to construct artificial nests for CBA. The artificial nests made from dried cocoa leaves as practiced in cocoa estates [15] and several types of artificial nests of CBA had been used by planters and researchers in Java, Indonesia, and Malaysia, as reported by Kalshoven [9] that banana or coconut leaves stuffed in bamboo were used in Java cocoa plantations to enhance CBA population. Ho and Khoo [20] made artificial nests from the plastic bag and Saleh [21] reported that the permanent nest made from polyester bag $35 \mathrm{~cm}$ x $40 \mathrm{~cm}$ with 30 to 40 holes filled with dried cocoa leaves could last more than five years without replacing the dried cocoa leaves and polyester bag.

The CPB control strategies for cocoa farmers in the Bahorok, Langkat District, are not complicated because the CBA population occurs naturally. Thus, very profitable for cocoa farmers. The population of antagonist ants is very low. Therefore, it helps to increase the CBA population. Antagonist ants are issues in some cocoa plantations because it disturbs the CBA population. Despite that, it is necessary to observe the condition of the cacao trees, which infested by CBA and CM. However, there should be special treatments on supporting the development of ant species on cacao without shade. The study was conducted to obtain an efficient strategy to control CPB that can be applied by farmers.

\subsection{Materials and Methods}

The study was conducted in smallholder cocoa farms at Timbang Jaya village in Bahorok, Langkat District, North Sumatra, from March 2018 to June 2019. The location is $03^{\circ} 03^{\prime}$ North and $96^{\circ} 06^{\prime}$ East, $92 \mathrm{~km}$ from Medan. The annual precipitation in this area is 3,000-4,000 $\mathrm{mm}$ per year and the peak of rainfall is in December to the middle of January. The conditions of cocoa trees were varied. Generally, smallholders planted the cocoa trees around houses with a total of 50-300 trees, but some were planted separately in the cocoa plantations with the total number of trees up to 900 . The cocoa trees planted with other plants, such as coconut, soursop, and rubber as shade trees, and in some areas, there were no shade trees with most of the cocoa trees had dieback symptoms. There were no fertilizer applications and pest control for more than two years.

The study was conducted at 10 smallholder cocoa farms. In each farm, we selected 10 sample trees. The total number of cocoa trees colonized by $\mathrm{CBA}$ and $\mathrm{CM}$ were counted. The presence of CBA and CM were recorded from harvested pods samples as well as CPB infestation. We harvested and separated the ripe pods with and without CBA and CM. All pods were examined to calculate the damage caused by CPB. The damages were grouped into free (uninfested pods), infested (all pods attacked by CPB), and severe damage pods (pods with $>50 \%$ unextractable seeds).

\subsection{Our Contribution}

This paper presents improvements for the establishment of CBA for controlling CPB in cocoa farmers. This founding could easily be adopted by cocoa farmers. The farmers could select the types of artificial nests of CBA depending on available materials in their location.

\subsection{Paper Structure}

The structure of the rest of this paper is Section 2 informs the potential of $\mathrm{CBA}$ and $\mathrm{CM}$ population and interaction with $\mathrm{CPB}$ infestation. 2.1. The strategy for controlling $\mathrm{CPB}$ is consists of the presence of $\mathrm{CBA}$ and $\mathrm{CM}$; trees occupied and without CBA and CM then area of cocoa trees without shade trees. 3. The conclusion of this paper is the need to observe the presence of ants before determining an efficient strategy.

\section{RESULTS AND DISCUSSION}

Overall, $62 \%$ of observed cocoa trees were occupied by CBA and CM (Table 1). Saleh et al. reported 14 tree species that act as shade trees and as the host of CBA and CM [7]. Four of 14 species were found in this study, i.e., coconut (Cocos nucifera), soursop (Annona muricata), kapok (Ceiba pentandra), and jackfruit (Artocarpus heterophyllus). CBA and CM populations could not be found in cocoa trees without shade. Most of the unshade trees were unhealthy, stressed, and infested by Vascular Streak Dieback caused by air-borne fungal pathogen Oncobasidium theobromae. Besides, CM prefers shaded habitats. Cocoa without shade trees has an open canopy with excessive light that penetrates tree parts under the canopy, which limiting the CM population growth. The high population of CM was found mostly in habitats with the intensity of light less than 200 lux [22]. As cocoa mealybug is the primary food source of cocoa black ants [24], therefore its abundance highly depending on the survival of CM. Hence, it is challenging to introduce CBA in cocoa monocultures that using insecticides to control pests, which resulted in a declining mealybug population [10]. 
Table 1 The survival of cocoa black ant (CBA) and cocoa mealybugs (CM) on the cocoa tree

\begin{tabular}{|c|c|c|c|c|}
\hline \multirow{2}{*}{ Location No } & \multirow{2}{*}{$\begin{array}{l}\text { Total trees } \\
\text { observed }\end{array}$} & \multicolumn{2}{|c|}{$\begin{array}{l}\text { Number of cocoa trees colonized by } \mathrm{CBA} \text { and } \\
\text { CM }\end{array}$} & \multirow{2}{*}{$\begin{array}{c}\text { Percentage of cocoa trees } \\
\text { colonized by CBA and } \\
\text { CM (\%) }\end{array}$} \\
\hline & & $\begin{array}{c}\text { Occupied by CBA and } \\
\text { CM }\end{array}$ & No CBA and CM & \\
\hline 1 & 10 & 3 & 7 & 30 \\
\hline 2 & 10 & 8 & 2 & 80 \\
\hline 3 & 10 & 10 & 0 & 100 \\
\hline 4 & 10 & 9 & 1 & 90 \\
\hline 5 & 10 & 7 & 3 & 70 \\
\hline 6 & 10 & 8 & 2 & 80 \\
\hline 7 & 10 & 5 & 5 & 50 \\
\hline 8 & 10 & 2 & 8 & 20 \\
\hline 9 & 10 & 8 & 2 & 80 \\
\hline 10 & 10 & 2 & 8 & 20 \\
\hline Total & 100 & 62 & 38 & 62 \\
\hline
\end{tabular}

The ripe pods from the 100 sample trees were harvested (Table 2). There were 179 pods examined with 104 pods occupied by CBA and CM, which $69.3 \%$ of pods were healthy, $30.7 \%$ of pods infested by CPB with $4.8 \%$ of infested pods were heavily damaged. Meanwhile, 75 pods without $\mathrm{CBA}$ and $\mathrm{CM}$ have $100 \%$ infested by $\mathrm{CPB}$, and $29.3 \%$ of infested pods were damaged heavily. In order to suppress CPB infestation below than $50 \%$ or the percentage of massive damage pod below than 5\%, the harvested pods should be occupied by CBA and CM should be above $70 \%$ $[12,22]$. These results are in line with the previous study, where the increasing population of $\mathrm{CBA}$ in the cocoa plantation significantly decreased the population of CPB [26].
The effectiveness of this biocontrol method of $\mathrm{CPB}$ depends on the population of CBA and CM in cocoa plantations, where it should high and sufficient [5, 15, 23]. Saripah [25] states that the control of CBP using black ants offer more promising results in comparison to pesticide and reduce the population of the borer significantly and increase more than $50 \%$ of healthy cocoa pods. Despite that, the integration of the biological control using the CBA and good cultural practices such as short harvesting round and burying the cocoa husk will increase the chance to reduce the population of the borer drastically and increase the cocoa yield $[16,22]$.

Table 2 The presence of cocoa black ant (CBA) and cocoa mealybugs (CM) on harvested cocoa pods and severity of CPB infestation

\begin{tabular}{|c|c|c|c|c|c|c|c|c|c|c|}
\hline \multirow[b]{3}{*}{ No } & \multicolumn{4}{|c|}{ Pods with CBA and CM } & \multicolumn{4}{|c|}{ Pods without CBA and CM } & \multirow{3}{*}{$\begin{array}{c}\text { Total } \\
\text { pods } \\
\text { observed }\end{array}$} & \multirow{3}{*}{$\begin{array}{c}\text { Total of } \\
\text { heavy } \\
\text { damaged } \\
\text { Pods }\end{array}$} \\
\hline & \multicolumn{4}{|c|}{ CPB infestation } & \multicolumn{4}{|c|}{ CPB infestation } & & \\
\hline & Total & Free & Infested & $\begin{array}{c}\text { Heavy } \\
\text { damaged }\end{array}$ & Total & Free & Infested & $\begin{array}{c}\text { Heavy } \\
\text { damaged }\end{array}$ & & \\
\hline 1 & 5 & 0 & 5 & 0 & 20 & 0 & 20 & 5 & 25 & 5 \\
\hline 2 & 10 & 7 & 3 & 1 & 3 & 0 & 3 & 0 & 13 & 1 \\
\hline 3 & 12 & 11 & 1 & 0 & 0 & 0 & 0 & 0 & 12 & 0 \\
\hline 4 & 9 & 8 & 1 & 0 & 3 & 0 & 3 & 1 & 12 & 1 \\
\hline 5 & 15 & 12 & 3 & 0 & 5 & 0 & 5 & 2 & 20 & 2 \\
\hline 6 & 18 & 13 & 5 & 1 & 10 & 0 & 10 & 3 & 28 & 4 \\
\hline 7 & 8 & 5 & 3 & 0 & 6 & 0 & 6 & 1 & 14 & 1 \\
\hline 8 & 4 & 0 & 4 & 2 & 10 & 0 & 10 & 2 & 14 & 4 \\
\hline 9 & 16 & 14 & 2 & 0 & 8 & 0 & 8 & 4 & 24 & 4 \\
\hline 10 & 7 & 2 & 5 & 1 & 10 & 0 & 10 & 4 & 17 & 5 \\
\hline & 104 & 72 & 32 & 5 & 75 & $\mathbf{0}$ & 75 & 22 & 179 & 27 \\
\hline$\%$ & & 69.3 & 30.7 & 4.8 & & 0 & 100 & 29.3 & & 15.1 \\
\hline
\end{tabular}


transfer two slices of cocoa husk occupied by CM to $5 \mathrm{~cm}$ length pods. The cocoa husk should be sliced thinly into $\mathrm{V}$ shape (Figure 2 a), and in a few days, CM will move to the fresh cocoa pod where they can suck their food $[13,22]$ (Figure $2 \mathrm{~b}$ ). supports the growth of CBA and CM populations. While not all cocoa trees have the advantages to grow under shade trees. Therefore, it is necessary to develop strategies to introduce the CBA and CM into those free shade tree areas and also strategies to maintain CBA and CM population. These are three strategies that can be used by the farmers in accordance with their farm conditions.

\subsubsection{Strategy for cocoa trees which occupied by $C B A$ and $C M$}

In order to improve the population of $\mathrm{CBA}$ and $\mathrm{CM}$ to more than $70 \%$ on harvested pods, it is enough to give each tree one empty artificial nest on the branches. The artificial nest of CBA can be made from 40 dried cocoa leaves and tied with raffia ropes (Figure 1a) or stuffed the 40 dried cocoa leaves to the plastic or polyester bag (Figure $1 \mathrm{~b}, \mathrm{c}$, d).
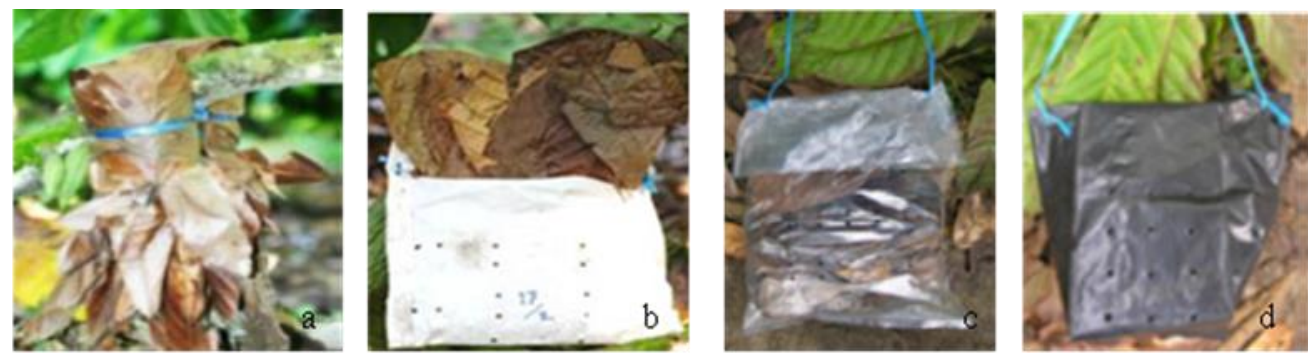

Figure 1 Various materials for CBA artificial nest: (a) artificial nest from dried cocoa leaves, (b) dried cocoa leaves in polyester bag, (c) dried cocoa leaves in transparent plastic bag, (d) dried cocoa leaves in black plastic bag

\subsubsection{Strategy for cocoa trees without $C B A$ and $C M$}

The artificial nest of CBA is made as mentioned above. The nest must be placed on trees occupied by CBA for at least two months so the nest will colonize by CBA. Then transfer the nests to trees with no CBA. At the same time,
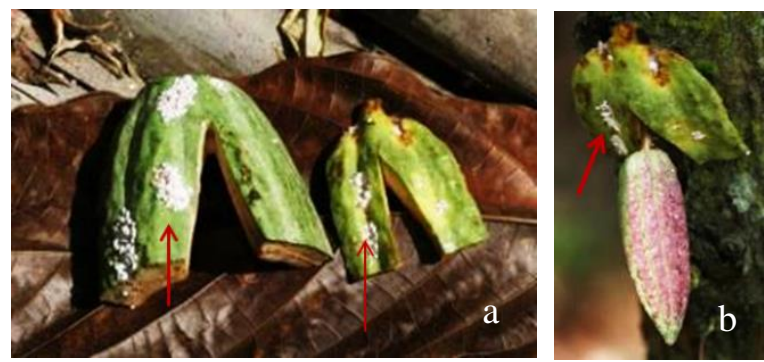

Figure 2 (a) Slices of cocoa pods with CM, (b) slice of cocoa skin and placed on $5 \mathrm{~cm}$ cocoa pods, Saleh[11]
Anshary et al. [26] the application of suitable for artificial nest is nipa palm leaves, but it has to be strengthened with synthetic materials that will sustain the CBA colonies in the cocoa plantation. Beside cocoa and coconut leaves, another natural material that suitable for artificial nests is nipa palm leaves, but it has to be strengthened with synthetic materials that will sustain the CBA colonies in cocoa plantation.

\section{CONCLUSION}

CBA and CM populations occurred naturally in cocoa plantations in Bahorok, so it is enough to install empty artificial nests in cocoa trees. Aside from artificial nests, shade trees also boost $\mathrm{CBA}$ and $\mathrm{CM}$ populations. These strategies combination will maintain $\mathrm{CBA}$ and $\mathrm{CM}$ populations so it can suppress $\mathrm{CPB}$ attacks. Whereas on trees without a shade where no CBA and CM populations, the farmers can transfer the artificial nests which have been occupied by CBA and CM to cocoa trees. 
[9] L.G.E. Kalshoven, Pests of Crops in Indonesia. (Revised by van der Laan, P.A. 1981). P.T. Ichtiar Baru. Jakarta, Indonesia, 1981, pp. 701

[10] C.T. Ho, Relationship between black cocoa ant, Dolichoderus thoracicus (Hymenoptera: Formicidae) abundance and cocoa borer, Conopomorpha cramerella (Lepidoptera: Gracillariidae) damage in a cocoa plantation. In: Proceedings of 4th International Plant Protection in Tropics. (Eds: A. Rajan \& Y.B. Ibrahim). Malaysian Plan Protection Society, Kuala Lumpur, 1994, pp. $214-215$

\section{REFERENCES}

[1] S. Wardojo, The cocoa pod borer- A major hindrance to cocoa development, IAARD 2(1) (1980) 2 - 4

[2] S. Wardojo, Kemungkinan pembebasan Maluku Utara dari pada masalah penggerek buah coklat, Acrocercops cramerella SN, Menara Perkeb. 52(3) (1984) 57-64

[3] P.C. Wessel, The cocoa pod borer moth, Review of research in Indonesia (1900-1918), In Guide Book, Theobromae, (eds. Indranada, H.T.K, et al.). International Conference on Cocoa Economy Bali, Indonesia, (1993) 42-47

[4] G.T. Lim, Biology, ecology and control of cocoa pod borer Conopomorpha cramerella (Snellen). In cocoa pest and disease management in Southeast Asia and Australia, (eds. P.J. Keane, C.A.J. Putter), FAO Plant Production and Protection Paper, FAO United Nations, Rome, 1992, pp. 85-100

[5] I. Azhar, An overview on the management of key Insect pests of cocoa with major emphasis on the cocoa pod borer, Conopomorpha cramerella. The Planter Malaysia. 71(835) (1995) 469-480

[6] I. Azhar, G.E. Long, M.J. Musa, Qualitative and multivariate analyses of clone cocoa resistance to cocoa pod borer (Lepidoptera: Gracillariidae). The Planter Malaysia, 71 (832) (1995) 307-321

[7] Dir. Jenbun. Statistik Perkebunan Indonesia Komoditas Kakao 2015-2017, Direktorat Jenderal Perkebunan Indonesia, Jakarta, 2017

[8] A. Saleh, Armaniar, A. Abu Hassan, Potensi Semut Hitam, Dolicoderus thoracicus Smith Dalam Mengendalikan Hama Penggerek Buah Kakao, Conopomorpha cramerella Snellen Pada Tanaman Kakao Petani di Kabupaten Langkat, Sumatra Utara. Prosiding Plant Protection Day 3 dan Seminar Nasional, 2018 , pp. 10-16, ISBN: $978-$ 602-439-566-7
[11] A. Saleh, Establishment of The Biological Control System by Black Ant, Dolichoderus thoracicus (Smith) (Hymenoptera: Formicidae) And Mealybug, Cataenococcus hispidus (Morrison) (Homoptera: Pseudococcidae) Against the Cocoa Pod Borer, Conopomorpha cramerella (Snellen) (Lepidoptera: Gracillariidae) in North Sumatra, Indonesia. Ph.D. Thesis, University Sains Malaysia, 2011.

[12] A.Saleh, Lonsum's experience in controlling the cocoa pod borer. 6th International Conference on Plant Protection in the Tropic. Kuala Lumpur, Malaysia. August 11-14, 2003, pp. 1-7

[13] A. Saleh, A. Abu Hassan, M.R. Che Salmah, Elimination of antagonist ants for establishment of black ant, Dolichoderus thoracicus (Smith) in controlling Helopeltis theobromae Miller and Conopomorpha cramerella Snallen in cocoa plantations. Malaysia Applied Biology Symposium. P. Penang, Malaysia. May 30-31, 2007, pp. 1-4

[14] A.H. Bakri, M. Asid, M.J. Redshaw, Pemberantasan Helopeltis secara terpadu dengan penggunaan semut hitam dan bahan kimia pada tanaman coklat di Sumatra Utara. (Using black ants and chemicals in an integrated approach to control Helopeltis in cocoa in North Sumatra). Temu Ilmiah Entomologi Perkebunan Indonesia. Medan, North Sumatra. April 22-24, 1996, p. 11

[15] A. Saleh, A. Abu Hassan, M.R. Che Salmah, Establishment of Dolichoderus thoracicus (Smith) to control Helopeltis theobromae Miller and Conopomorpha cramerella (Snellen) in Lonsum cocoa plantations Indonesia. IMT-GT Conference. Medan, Indonesia 22-23, 2006, pp. 1-5

[16] A. Saleh, A. Abu Hassan, M.R. Che Salmah, Strategies in Controlling Conopomorpha cramerella (Snellen) (Lepidoptera: Gracillariidae) in Lonsum cocoa plantations, Indonesia. 
Applications of biological agents and pruning

IPICEX2006 conference. Kuala Lumpur, Malaysia. 26-29, 2006, pp. 1-6

[17] A.B. Attygalle, A. Mutti, W. Rohe, U. Maschwitz, W. Garbe, H.J. Bestmann, Trail pheromone from pavan gland of the ant Dolichoderus thoracicus (Smith). Naturwissenschaften, (85) (1998) 275277.

DOI: http://dx.doi.org/10.1007/s001140050498

[18] K.C. Khoo, K.F. Chung, Use of the black cocoa ant to control mirid damage in cocoa. The Planter 65 (1989) 370-383

[19] B. Holldobler, E.O.Wilson, The ants. Harvard University Press, 1990.

[20] C.T. Ho, K.C. Khoo, Some factors influencing sustenance of high activity of black cocoa ant, Dolichoderus thoracicus (Hymenoptera: Formicidae) in cocoa estates. In Proceedings of the 4th International Plant Protection in the Tropics. (Eds: A. Rajan \& Y.B. Ibrahim). Malaysian Plant Protection Society, Kuala Lumpur Kuala, Malaysia. March 28-31, 1994, pp. 218-220

[21] A. Saleh, Studi berbagai jenis sarang permanen untuk mengembangbiakkan semut hitam, Dolichoderus thoracicus (Smith) (Hymenoptera: Formicidae). JEI. 9(2) (2012) 64-70, DOI: http://doi.org./10.5994/ jei.9.2.64

[22] A. Saleh, Distribution of Cocoa Pod Borer (CPB), Conopomorpha cramerella (Snellen) and Potential of using Cocoa Black Ant (CBA), Dolichoderus thoracicus (Smith) and Cocoa Mealybugs (CM), Cataenococcus hispidus Morrison as biological control Agent in Lonsum Estates, North Sumatra Indonesia. M.Sc. Thesis, Universiti Sains Malaysia. 2003, p. 150.

[23] M.J. Way, K.C. Khoo, Colony dispersion and nesting habits of ants, Dolichoderus thoracicus and Oecophylla smaragdina (Hymenoptera: Formicidae) in relation to their success as biological control agent on cocoa, Bulletin of Entomological Research 81, 1991, pp. 341-350.

[24] C.T. Ho \& K.C. Khoo, Partners in biological control of cocoa pests; Mutualism between Dolichoderus thoracicus (Hymenoptera: Formicidae) and Cataenococcus hispidus (Hemiptera: Pseudococcidae). Bull. Entomol. Res. 87 (5) (1997) 61-470

[25] B. Saripah. Control of cocoa pod borer using insecticides and cocoa black ants. Malaysian Cocoa Journal, 8 (2014) 14-22

[26] A. Anshary, M. Basir-Cyio, U. Hasanah, S. Mahfudz. Saleh, Nur Edy \& F. Pasaru. effectively control cocoa pod borer. Asian J. Crop Sci. 9(4) (2017) 125- 32

[27] B. Saripah, Sustaining cocoa black ant Dolichoderus thoracicus (Smith) using artificial nest in the cocoa ecosystem, Malaysian Cocoa Journal, (8) (2014) 23-30

[28] C.T. Khoo \& K.C. Ho, The influence of Dolichoderus thoracicus (Hymenoptera: Formicidae) on losses due to Helopeltis theivora (Heteroptera: Miridae), black pod disease, and mammalian pests in cocoa in Malaysia. Bull. Entomol. Res. 82 (4) (1992) 485 - 491

[29] S.M. Philpott \& I. Armbrecht, Biodiversity in tropical agroforests and the ecological role of ants and ant diversity in predatory function. Ecol. Entomol. 31(4), 2006, pp. $369-377$

[30] A. Gassa, A. Fatahuddin, T. Abdullah, M. Junaid, Black Ant (Dolichoderus thoracicus): Artificial diet and nest prospects in controlling cocoa pod borer (Conopomorpha cramerella Sn.). RJPBCS. 7(4) (2016) $3185-3191$ 